Iegarded as representing the usage approved by the Society. The material has been prepared with a great deal of care, and after consultation with those who are interested in the cause of good chemical nomenclature in this country. The rules agree very closely with what is considered the best usage in Great Britain. Copies of the Directions can be obtained by addressing Chemical Abstracts, Ohio State University, Columbus, Ohio.

\section{ESTIMATION OF PHENOL IN THE PRESENCE OF THE THREE CRESOLS-CORRECTION}

In the article printed under the above title [THIs Journal, Io (1918), 9] the following corrections should be made:

Page $I$, , right-hand column, $4^{\text {th }}$ line from the bottom should read: " $2.73^{\circ} \mathrm{C}$.," in place of " $2.75^{\circ} \mathrm{C}$."

Page I2, left-hand column, 6 th to Ioth lines from the top read: "Per cent phenol $=\frac{I .00}{2.73}\left(T_{0}-T_{s o}\right)-\frac{I .00}{0.0003367}\left(G_{0}-G_{s o}\right)$ or, Per cent phenol $=0.366\left(\mathrm{~T}_{0}-\mathrm{T}_{s 0}\right)-2970\left(\mathrm{G}_{0}-\mathrm{G}_{s 0}\right)(\mathrm{I})$ in the case of $o$-cresol $+p$-cresol + phenol mixtures; and, Per cent phenol $=0.585\left(\mathrm{~T}_{o}-\mathrm{T}_{\text {so }}\right)-2780\left(\mathrm{G}_{0}-\mathrm{G}_{s o}\right)$ (II) in the case of $o$-cresol $+m$-cresol + phenol mixtures" in place of
"Per cent phenoi $=\frac{\mathrm{I} .00}{2.73}\left(\mathrm{~T}_{a}-\mathrm{T}_{\text {so }}\right)-\frac{\mathrm{I} .00}{0.0003367}\left(\mathrm{G}_{0}-\mathrm{G}_{\text {so }}\right)$

or, Per cent phenoi $=0.366\left(\mathrm{~T}_{0}-\mathrm{T}_{\text {so }}\right)$

Per cent phenol $=0.585\left(\mathrm{~T}_{o}-\mathrm{T}_{s o}\right)-2780\left(\mathrm{G}_{0}-\mathrm{G}_{s o}\right)$ (II)."

Page 17 , right-hand column, 5 th line from the bottom should read: " 3 to $4{ }^{\circ} \mathrm{C}$.," in place of " 3 to $40^{\circ} \mathrm{C}$."

Page I8, right-hand column, $25^{\text {th }}$ line from the top should read: "zor ${ }^{\circ} \mathrm{C}$. (corr.)" in place of " $197^{\circ} \mathrm{C}$." G. W. KNIGHT, C. T. LinCoLn, et al.

\section{ELECTRIC FURNACE SMELTING OF PHOSPHATE ROCK, ETC.-CORRECTION}

The following corrections should be made in the article printed under the above head in THIS JOURNAL, Io (I9I8), 35 .

Page 37, and col., I Ith line from bottom should read: " 7800 tons phosphate rock @ \$4.50 per ton....\$35, 10o.oo."

Page 37, and col, 7th line from bottom should read: "8 laborers@\$2.00 per day (330 day year)....\$5,280.00."

Page 37, 2nd col., 3rd line from bottom should read: "Power @ \$25.00 per H. P. Y.....\$100,000.00."

\title{
WASHINGTON LETTER
}

By PAUL Wooton, Metropolitan Bank Building, Washington D. C.

Embargoes, idle Mondays and transportation delays have added materially to the burden of those in Washington who are trying to be helpful in speeding up the production of chemicals and in assisting the government to secure its ever-increasing requirements of the so-called war chemical supplies. There has been no retardation, however, of the activities of the many prominent chemists and of those importantly connected with chemical industries, who are busily engaged in Washington. Research is being conducted and various projects carried into effect which, if they could be made public, would give ample basis for spectacular display in newspapers and doubtless would surprise the great majority of the country's chemists. For military reasons, however, the more important things which are being done by chemists in Washington must not be discussed. The care that is being taken to maintain secrecy in connection with some activities is indicated by the fact that the correspondent of THIS JOURNAL, has been requested by a high official not to mention in this correspondence the names of certain prominent chemists who are being called into consultation here or who have been assigned to war work in Washington.

Following its first annual meeting in New York, February 6, The Chemical Alliance, Inc, has been able to get down to result-getting work, which was not possible to the same degree prior to a definition of all its policies and a systematic outline of its work.

Chemicals imported during the year just closed were valued at $\$ 144,2,35,400$. This compares with $\$$ I25,8I3,205 for the year I9I6. During December I9I7, the value of all imports of chemicals was $\$ 14,036,740$. This is a decided increase over December of I9I6, when the total value of all chemicals imported was $\$ 8,487,809$.

All chernicals exported during I 9 I 7 were valued at $\$ 193,255,160$. This is a substantial increase over I9I6, when the aggregate value of all chemicals exported was $\$ 165,286,008$. Exports of dyes and dyestuffs more than doubled. In I9I7 the value was $\$ 16,107,36$ I as compared with $\$ 7,953,986$ in 1916 and $\$ 2,510,650$ in Igr 5. Sulfuric acid exports in I9I 7 fell slightly below those of the year preceding. The I9I 7 exports were $63,542,930$ lbs. as compared with $66,463,5$ or $1 \mathrm{bs}$. in 1916 . The total value of all acid exports in I9I7 was $\$ 52,695,640$ as compared with $\$ 45,015,464$ in 1916. The principal increase in the chemicals exported to any single country was to the United Kingdom.

President Wilson has appointed, on recommendation of Secretary of the Treasury McAdoo, the following members of the Assay Commission: Representative Wm. A. Ashbrook, Johnstown, Ohio; Dr. W. P. Hillebrand, Bureau of Standards, Wash inton; Dr. Marcus Benjamin, Washington; Will H. Rounds, Sioux Falls, South Dakota; Kenneth M. Simpson, San Francisco;
Louis A. Fischer, Washington; Dr. Geo. F. Kunz, New York; John L. McNeill, Durango, Col.; W. P. Morris, New Hampshire; L. V. Bassett, Rock Mount, Salem, Ill.; Samuel Newhouse, Salt Lake City; Calvin Page, Portsmouth, N. C.; A. C. Weiss, Duluth; J. H. O'Neil, Boston; L. W. Nieman, Milwaukee; Martin H. Glynn, Albany; Roy W. Keehn, Chicago; S. B. Amidon, Wichita, Kan.; Robert P. Oldham, Seattle.

Arrangements have been made by the United States Geological Survey to secure weekly reports as to output from all by-product coke manufacturers in the country. From these reports, the Survey is compiling weekly a statement showing to what per cent of capacity plants are being operated. The reports also show the factors limiting production. The last report shows that the plants of the country were operated at 70.6 per cent of capacity. Failure to secure coal caused a loss of 23.8 per cent; repairs to plants, a loss of 2.8 per cent; car shortage and other causes, 2.8 per cent.

Published reports that ample ammonia will be available for ice making next summer forced from the Food Administration an admission that the ammonia shortage is acute and that it is likely to become necessary to commandeer it.

Volunteer chemists are addressing millers and bakers throughout the country on the technical phases of milling requirements and how best to utilize wheat substitutes in "Victory" bread and other war-time doughs. The work is under the direction of the United States Food Administration.

Cancellation of the car-load rate on hydrofluoric and hydrofluosilicic acids from Newell, $\mathrm{Pa}$., to Columbus, Ohio, has been asked by the Baltimore and Ohio Railroad in an application to the Interstate Commerce Commission. The same carrier also has asked permission to increase car-load rates on sulfuric and muriatic acids from Moundsville, W. Va., to points in Maryland, Pennsylvania and West Virginia. Carriers handling imported nitrate of soda, iron pyrites, chrome and manganese ores have requested increased rates from the seaboard to various of the consuming centers.

Exceeding in importance any other circumstance affecting the fertilizer industry is the inability to secure transportation of phosphate rock. Shortage has become so acute that several sulfuric acid plants will be forced to close, owing to their inability to store acid which ordinarily is mixed immediately on manufacture with the phosphate. Even a more serious side to the phosphate rock situation is the fact that fertilizer shipments are being delayed. Since 5,000,000 tons, out of a total movement of $7,000,000$ tons of fertilizers, must move before the end of March in order to be available for this year's use, the consequences of any delay at this time are certain to be far-reaching. After one 